Kamil Weber

Uniwersytet Opolski

\title{
Kandydaci Partii Demokratycznej i Republikańskiej wobec przemian społeczno-gospodarczych. Analiza na przykładzie wyborów prezydenckich z lat 2008 i 2012
}

DOI: 10.19195/1643-0328.20.7

Słowa kluczowe: partia, demokratyczna, republikańska, wybory, przemiany

\section{Wprowadzenie}

W amerykańskim społeczeństwie w ostatnich latach następują przemiany na wielu płaszczyznach. Widocznemu zjawisku liberalizacji środowisk wielkich miast i wybrzeży towarzyszy jednoczesne umacnianie konserwatyzmu grup związanych głównie z prawicowym odłamem Partii Republikańskiej czyli Tea Party. Stronnictwo to, będące wyrazem sprzeciwu wobec upowszechniania się postaw liberalnych, zyskuje coraz większe wpływy. W Stanach Zjednoczonych następują też wyraźne zmiany struktury narodowościowej, a kryzys gospodarczy dodatkowo wzmocnił zróżnicowanie poziomu życia poszczególnych grup społecznych. Zjawiska te wymuszały odpowiednią reakcję elit politycznych. Warto się zatem zastanowić, jak na nowe potrzeby reagowali przedstawiciele dwóch najważniejszych amerykańskich partii. Rozpoznanie tendencji i oczekiwań występujących w społeczeństwie Stanów Zjednoczonych oraz adekwatna odpowiedź na nie, miały istotne znaczenie w zwiększeniu szans na obsadzenie urzędu prezydenta, posiadającego znaczący wpływ na politykę tego państwa. Zgodnie z artykułem drugim amerykańskiej konstytucji, jest mu bowiem powierzona całość władzy wykonawczej ${ }^{1}$.

Zmiany zachodzące w omawianym okresie powodowały nie tylko umocnienie konfliktu poglądowego pomiędzy przedstawicielami Demokratów i Republikanów. Zauważalne były również rozbieżności w obrębie samych partii, co powodowało kształtowanie

1 A. Pułło, Wstęp, [w:] Konstytucja Stanów Zjednoczonych Ameryki, red. L. Garlicki, Warszawa 2002, s. 29. 
się frakcji i zaostrzenie wewnątrzpartyjnej retoryki. Można zauważyć, że skuteczniej na oczekiwania społeczne reagowali kandydaci Partii Demokratycznej. W obliczu zauważalnych zmian zachodzących w społeczeństwie Stanów Zjednoczonych, wprowadzenie odpowiedniej korekty programowej ze strony Partii Republikańskiej może jednak znacząco zwiększyć ich szanse w kolejnych wyborach.

\section{Przełomowe wybory}

Wybory z 2008 roku były wyjątkowe ze względu na to, że po raz pierwszy od 1952 roku nie startował w nich ani urzędujący prezydent, ani wiceprezydent. Spowodowało to autentyczną walkę o nominację zarówno w Partii Demokratycznej, jak i Republikańskiej². Ugrupowania te zdecydowanie dominują na amerykańskiej scenie wyborczej, a pozostałe formacje mają jedynie znaczenie marginalne i nie decydują o obliczu polityki Stanów Zjednoczonych. Należy zauważyć, że w swych założeniach ideologicznych Demokraci i Republikanie prezentują znaczne różnice ${ }^{3}$. Partia Demokratyczna jest określana jako bardziej liberalna. Jej lewicowe oblicze przejawia się w zwalczaniu nierówności społecznych, zwiększaniu wydatków na cele społeczne oraz większej tolerancji obyczajowej. Partia Republikańska jest natomiast postrzegana jako konserwatywna prawica. Opowiada się za przywiązaniem do tradycji oraz wartości rodzinnych i religijnych. Ważny dla Republikanów jest kult przedsiębiorczości i pracy. Postulują także ograniczanie wydatków budżetowych ${ }^{4}$.

Rok 2008 był bardzo trudny zarówno dla USA, jak i całej społeczności międzynarodowej. Światowy kryzys gospodarczy wpłynął w dużym stopniu na pogorszenie stopy życiowej Amerykanów. Społeczeństwo, w większości negatywnie oceniające rządy George’a W. Busha, żądało skutecznej walki z zapaścią oraz zmian w polityce społecznej i gospodarczej. Przed wyborami prezydenckimi w 2008 roku stawiało to kandydatów $\mathrm{w}$ trudnej sytuacji, gdyż musieli oni sprostać tym oczekiwaniom ${ }^{5}$.

Pogarszającą się wówczas sytuację materialną społeczeństwa Stanów Zjednoczonych prezentował między innymi Sławomir Grzegorz Kozłowski. Zwracał on uwagę na rosnącą liczbę osób żyjących poniżej progu ubóstwa. Wyniki badań prowadzonych przez Luxembourg Income Study wykazały, że w 2008 roku za osoby ubogie można było uznać $18 \%$ amerykańskiego społeczeństwa, czyli była to wartość niemal dwa razy wyższa niż w przypadku państw europejskich. Problem stanowił także wzrost liczby bezdomnych. Widoczne w tym kontekście stawało się rozwarstwienie społeczeństwa. W 2005 roku około 12 mln osób w Stanach Zjednoczonych żyło na ulicy, podczas gdy $12 \mathrm{mln}$ domów

2 C.E. Smidt et al., The Disappearing God gap? Religion in the 2008 presidential election, New York 2010, s. 4.

${ }^{3}$ W. Żebrowski, Teoria współczesnych systemów politycznych, Olsztyn 2009, s. 154.

4 B. Dziemidziok-Olszewska, System polityczny Stanów Zjednoczonych, [w:] Współczesne systemy polityczne, red. M. Żmigrodzki, B. Dziemidziok-Olszewska, Warszawa 2007, s. 162.

${ }^{5}$ F. Zakaria, Koniec hegemonii Ameryki, Warszawa 2009, s. 17. 
było niezamieszkanych. Były to drugie i trzecie domy zamożnych rodzin, najczęściej białej społeczności, a rzesze bezdomnych stanowili głównie przedstawiciele rasy czarnej i Latynosi. Za taki stan rzeczy wspomniany autor winił również administrację Busha, gdyż to za jego rządów nastąpiło obniżenie wydatków na pomoc dla najuboższych. Problem biedy przybrał w USA charakter rasowy. Świadczy o tym fakt, że w 2005 roku odsetek osób białych o dochodach poniżej progu ubóstwa wynosił 8,3\%, wśród ludności latynoskiej $21,8 \%$, a czarnej aż $24,9 \%$. Wynikało to zarówno z dyskryminacji, jak i gorszej pozycji na rynku pracy spowodowanej trudnym dostępem do edukacji dla przedstawicieli tych środowisk ${ }^{6}$.

Taki stan rzeczy wymusił odpowiednią reakcję głównych sił politycznych. Przed wyborami prezydenckimi w 2008 roku w panujące nastroje społeczne dobrze wpisywał się zyskujący coraz większą popularność Barack Obama. Został on wychowany przez matkę $\mathrm{w}$ duchu sprawiedliwości społecznej i tolerancji ${ }^{7}$. Wielokulturowość i zmiany otoczenia, których doświadczał, wpłynęły na jego wrażliwość w kwestiach rasowych ${ }^{8}$. W młodości angażował się między innymi $\mathrm{w}$ działania fundacji pomagającej ubogim w Chicago' Jego zainteresowanie równością szans wszystkich obywateli objawiło się także w 2004 roku, kiedy wygłosił mowę podczas konwencji Partii Demokratycznej. Obama mówił wtedy, że niezależne od rasy czy pochodzenia Stany Zjednoczone muszą być państwem bez dyskryminujących podziałów ${ }^{10}$.

Oprócz niego, w prawyborach Partii Demokratycznej kluczową rolę odgrywała również Hillary Clinton ${ }^{11}$. Tomasz Tabako scharakteryzował podział, który dokonał się pomiędzy ich zwolennikami. Jego zdaniem, elektorat Baracka Obamy tworzyli głównie ludzie młodzi, wykształceni i zaradni pod względem ekonomicznym, którzy wcześniej nie zaangażowali się w politykę, ale byli już zmęczeni dotychczasową sytuacją w kraju i poszukiwali zmian. Clinton zaś zyskała poparcie głównie emerytów, katolików, ludzi słabiej wykształconych i tych, którzy na skutek kryzysu stracili pracę. W większości popierały ją też kobiety i ludność biała, podczas gdy Obama zdecydowanie prowadził wśród społeczności czarnej i imigrantów ${ }^{12}$. W swoim programie senator Clinton zawarła między innymi sprzeciw wobec przenoszenia produkcji przemysłowej za granice Stanów Zjednoczonych, konieczność wdrażania ekologicznej polityki energetycznej i program powszechnych ubezpieczeń. Obama, najwięcej uwagi poświęcał natomiast kwestii

6 S.G. Kozłowski, Bieda po amerykańsku, „Le Monde Diplomatique” 2008, nr 5, s. 14-15.

7 P. Laidler, Na czym polega fenomen Baracka Obamy?, [w:] Wybory w USA - z zagadnień teorii i praktyki, red. B. Bednarczyk, „Krakowskie Studia Międzynarodowe”, Kraków V, 2008, nr 3, s. 88.

8 Punkty za pochodzenie. Wywiad Marka Ostrowskiego z Christophem von Marschallem, „Polityka”, 20.09.2008, s. 57.

9 T. Zalewski, Kościoły czarne i białe, „Polityka”, 31.03.2008, s. 55.

10 E. Sarnecka-Mahoney, Odziedziczona rewolucja. Dlaczego Obama, dlaczego teraz, co dalej z ta Ameryka, Warszawa 2009, s. 33-34.

11 B. Norrander, Democratic marathon, republican sprint. the 2008 presidential nominations, [w:] The American elections of 2008, red. J.M. Box-Steffensmeier, S.E. Schier, Maryland 2009, s. 40-41.

12 Obamiacy, hillaryści, makkejnowcy. Wywiad Jarosława Makowskiego z Profesorem Tomaszem Tabako, „Polityka”, 21.06.2008, s. 50. 
problemów rasowych, konieczności większej solidarności społecznej i krytyce kręgów wielkiego biznesu wykorzystującego jednostki ${ }^{13}$. Ich wewnątrzpartyjna walka miała negatywny wpływ na pozycję Demokratów przed rozpoczęciem rywalizacji z kandydatem Republikanów ${ }^{14}$. Ostatecznie jednak na konwencji w Denver Obama otrzymał solidarne poparcie członków swojego ugrupowania ${ }^{15}$.

W przypadku Partii Republikańskiej po krytykowanych rządach George’a W. Busha, jedność i silne poparcie swojego kandydata były bardzo potrzebne. Stosunkowo szybko głównym pretendentem do otrzymania partyjnej nominacji stawał się John McCain ${ }^{16}$. Spore szanse dawano jednak także Mike’owi Huckabee, byłemu gubernatorowi stanu Arkansas. Jako pastor kościoła baptystów, bardzo często odwoływał się on do znaczenia religii i gospodarczego populizmu ${ }^{17}$. Swoją kandydaturę zgłosił także Ron Paul — zwolennik obniżania podatków, znany ze swego sprzeciwu wobec interwencjonizmu państwowego ${ }^{18}$.

Do rywalizacji z Barackiem Obamą — zgodnie z przewidywaniami - wyznaczony został jednak McCain. Bardzo istotne w czasie kryzysu były poglądy kandydatów dotyczące sposobów poprawy sytuacji gospodarczej. Obama wierzył w mechanizmy wolnego rynku, ale uważał, że regulacje wprowadzone przez administrację także będą konieczne. W swoim programie wyborczym opowiadał się za obniżeniem podatków obywatelom średnio i mniej zarabiającym, a podwyższeniem ich zarabiającym ponad 250 tys. USD rocznie. Postulował też rozszerzenie świadczeń dla bezrobotnych oraz wprowadzenie ulg podatkowych dla firm tworzących nowe miejsca pracy ${ }^{19}$. Opowiadał się także za wprowadzeniem planu stymulacji gospodarki o kapitale 50 mld USD, którego celem bylaby odbudowa infrastruktury ${ }^{20}$.

McCain natomiast proponował uproszczenie systemu podatkowego poprzez wprowadzenie dwóch niższych progów podatkowych i ulg. Chciał również stworzyć plan cięć podatkowych dla przedsiębiorstw oraz postulował zamrożenie wydatków publicznych poza sektorem obrony narodowej i programów pomocowych. Pomimo różnic w doktrynach wyznawanych przez obie partie, zarówno Obama, jak i McCain opowiadali się zatem za aktywną rolą władz w zwalczaniu kryzysu. Program Obamy był jednak bardziej zorientowany na kwestie socjalne. Zgodnie z nim, państwo miało ponosić większe

13 M. Ostrowski, Do kogo zadzwoni Ameryka?, „Polityka”, 5.04.2008, s. 47.

14 T. Zalewski, Czy w Denver poleje się krew?, „Polityka”, 3.05.2008, s. 47-48.

15 J.A. Gans Jr., The democratic primaries, [w:] The 2008 presidential elections. A story in four acts, red. E. Jones, S. Vassallo, New York 2009, s. 19-20.

16 S.H. Duggin, M.B. Collins, The American presidency, the 2008 election, and the U.S. constitutions natural born citizens proviso, [w:] Wybory w USA ..., s. 61.

17 C.E. Smidt et al., op. cit., s. 74-75.

18 A. Rosenthal, Now for a real Underdog, Ron Paul, Libertarian, for president, www.nytimes. com/1988/10/17/us/now-for-a-real-underdog-ron-paul-libertarian-for-president.html (dostęp: 16. 08.2013).

19 C.E. Smidt et al., op. cit., s. 144.

20 J. Gibson, A Brief look at candidate Obama's 2008 campaign promises, www.foxnews.com/politics/2011/04/05/brief-look-at-candidate-obama-2008-campaign-promises (dostęp: 9.01.2015). 
obciążenia wynikające z pokrycia kosztów wsparcia dla osób znajdujących się w gorszej sytuacji majątkowej ${ }^{21}$.

W kwestiach obyczajowych kandydaci także byli wierni linii programowej swoich ugrupowań. Obama prezentował bardziej liberalne nastawienie, między innymi w odniesieniu do praw homoseksualistów. Sprzeciwiał się małżeństwom osób tej samej płci, ale też kwestionował ich konstytucyjny zakaz. W przeciwieństwie do niego, McCain prezentował stanowisko bardziej konserwatywne, opowiadając się za wartościami rodzinnymi i sprzeciwiał się przywilejom homoseksualistów, stawiających ich związki na równi z małżeństwami. Kandydaci popierali także stanowiska swoich partii wobec aborcji. Demokraci uważali, że kobiety mają w tej kwestii prawo wyboru. Republikanie natomiast na piedestale stawiali prawo do życia ${ }^{22}$. Obama równoważył jednak swój wizerunek, będąc pierwszym od lat kandydatem Demokratów otwarcie odwołującym się do religii, a jego polityka prospołeczna postrzegana była na kształt chrześcijańskiego miłosierdzia ${ }^{23}$. Program Obamy był też przychylny wobec imigrantów. Demokraci chcieli co prawda walczyć z pracodawcami nielegalnie zatrudniającymi osoby przybyłe z zagranicy, ale też postulowali, by zwiększyć odsetek imigrantów, którym należy umożliwić stanie się pełnoprawnymi obywatelami. Obama mówił również o promowaniu rozwoju gospodarczego w Meksyku, aby zmniejszyć poziom nielegalnej imigracji ${ }^{24}$.

Obama, między innymi dzięki lepszemu dostosowaniu programu wyborczego do wymagań ówczesnej sytuacji społeczno-gospodarczej, zdecydowanie wygrał wybory. Uzyskał on najkorzystniejszy wynik w głosowaniu powszechnym zanotowany przez kandydata Demokratów od czasu wyboru Lyndona Johnsona w $1963 \mathrm{roku}^{25}$. Interesujących wyników dostarcza analiza tego, jak rozkładało się poparcie dla kandydatów w zależności od przynależności etnicznej wyborców. Należy zwrócić uwagę, że znaczenie mniejszości rasowych $\mathrm{w}$ amerykańskich wyborach prezydenckich stale wzrasta ${ }^{26}$. Poniższy wykres przedstawia odsetek poszczególnych ras wśród amerykańskich wyborców od 1988 do 2008 roku. Można na nim zaobserwować systematyczny wzrost liczby ludności czarnej, latynoskiej i azjatyckiej oraz zmniejszający się o ponad 8,5\% w ciągu 20 lat udział wyborców białych.

${ }^{21}$ M. Ostrowski, op. cit., s. 47.

22 C.E. Smidt et al., op. cit., s. 146.

${ }^{23}$ Co się stało w Ameryce? Wywiad Jacka Żakowskiego z Radosławem Markowskim, „Polityka”, 8.11.2008, s. 90 .

24 Blueprint for change, Obama and Biden's Plan for America, www.slideshare.net/arepb/blueprint-forchange-obamas-plan-for-america-presentation (dostęp: 11.01.2015).

25 J. Heilemann, M. Halperin, Game change, Obama and the Clintons, McCain and Palin, and the race of a lifetime, New York 2010, s. 429.

${ }^{26}$ N.W. Polsby et al., Presidential elections, Strategies and structures of American politics, Maryland 2012, s. 27. 


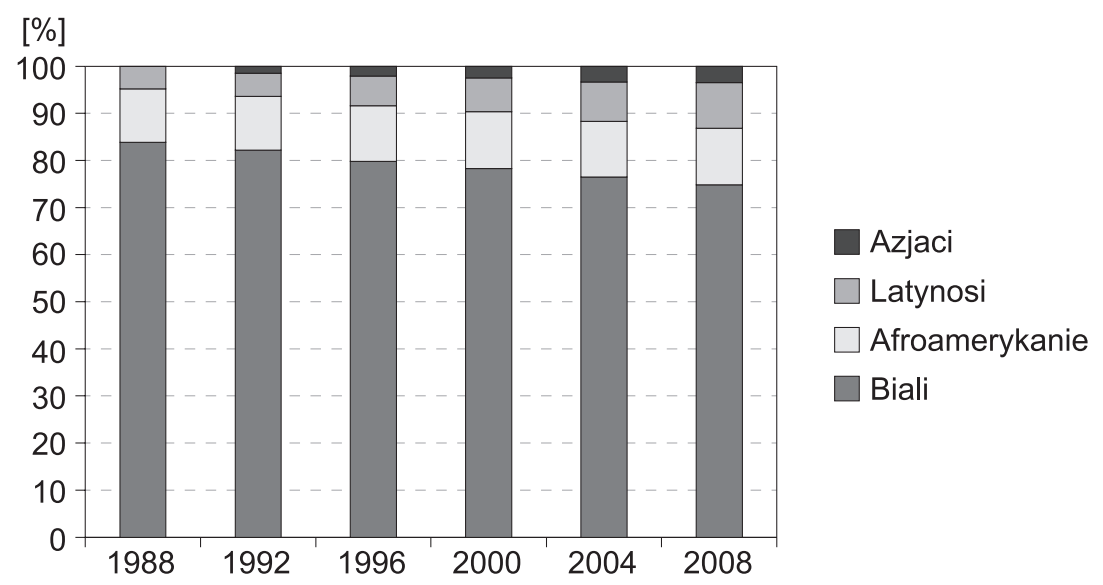

Rycina 1. Procentowy udział głosujących różnych ras w amerykańskich wyborach prezydenckich w latach 1988-2008

Źródło: www.pewhispanic.org/2009/04/30/dissecting-the-2008-electorate-most-diverse-in-us-history/ (dostęp: 13.01.2015).

Pozyskanie przychylności grup obcego pochodzenia staje się coraz istotniejsze i przy wyrównanej walce pomiędzy kandydatami może zadecydować o jej wyniku. Obama opowiadał się za bardziej liberalną polityką wobec imigrantów oraz mniejszości. Mogło to spowodować jego przewagę w tej grupie elektoratu (tab. 1).

Tabela 1. Porównanie poparcia dla Baracka Obamy i Johna McCaina wśród przedstawicieli różnych ras

\begin{tabular}{l|c|c}
\hline \multicolumn{1}{c|}{ Grupa wyborców } & Poparcie dla Baracka Obamy (\%) & Poparcie dla Johna McCaina (\%) \\
\hline Biali & 43 & 55 \\
\hline Afroamerykanie & 95 & 4 \\
\hline Latynosi & 67 & 31 \\
\hline Azjaci & 62 & 35 \\
\hline Inni & 66 & 31 \\
\hline
\end{tabular}

Źródło: W. Modzelewski, USA w sondażach, Warszawa 2012, s. 81.

Analizując powyższe dane, można stwierdzić, że McCain zwyciężył tylko w głosowaniu przedstawicieli białej społeczności. Obama natomiast zdecydowanie triumfował, jeśli chodzi o poparcie ze strony wszystkich mniejszości rasowych. Szczególną uwagę zwraca fakt, że wśród ludności afroamerykańskiej uzyskał aż 95\% głosów. Wiązało się to z możliwością identyfikowania się tej społeczności z nim ze względu na jego pochodzenie. Znaczenie miał też wspomniany program działań, bardziej przychylny mniejszościom oraz postulujący pomoc ze strony państwa dla osób znajdujących się w trudnej sytuacji materialnej, wśród których ludność czarna oraz latynoska stanowią sporą część ${ }^{7}$.

27 A. Barr, 2008 turnout shatters all records, www.politico.com/news/stories/1108/15306.html (dostęp: 12.01.2015). 
Warto dodać, że wśród Latynosów Obama uzyskał wynik aż o 14\% lepszy niż kandydat Demokratów w poprzednich wyborach, czyli John Kerry ${ }^{28}$.

Interesujących wyników dostarcza także analiza rozkładu poparcia dla kandydatów ze względu na poziom dochodów. Widać tutaj wyraźną tendencję świadczącą o tym, że im w danej grupie były one niższe, tym Obama zyskiwał większą przewagę nad swoim rywalem. Przykładowo wśród wyborców, którzy zarabiali mniej niż 15 tys. USD rocznie, Obama uzyskał 73\% głosów. W grupie zarabiającej od 30 do 50 tys. USD zdobył ich natomiast jedynie $55 \%{ }^{29}$. Kandydat Partii Demokratycznej, zgodnie z przewidywaniami, odniósł też zdecydowane zwycięstwo wśród osób o orientacji homoseksualnej. Jego bardziej liberalny program w kontekście obyczajowości zapewnił mu poparcie 70\% przedstawicieli mniejszości seksualnych ${ }^{30}$.

Wybory w 2008 roku odbywały się w przełomowym dla amerykańskiego społeczeństwa momencie. Pogarszająca się sytuacja ekonomiczna i zmęczenie rządami administracji George’a W. Busha spowodowały zainteresowanie się polityką osób do tej pory nieaktywnych $\mathrm{w}$ tej sferze ${ }^{31}$. Obama jawił się jako nowa nadzieja, a charyzma, przygotowanie merytoryczne i innowacyjna kampania pozwoliły społeczeństwu uwierzyć w możliwość zmiany, którą miała wyróżniać się jego prezydentura ${ }^{32}$.

\section{Kolejna przegrana Republikanów}

W 2012 roku w prawyborach Partii Republikańskiej zarysowała się silna rywalizacja. Nastąpił rozłam na opcję laicką, której przedstawicielem był przede wszystkim biznesman Mitt Romney, oraz opcję popieraną przez konserwatystów religijnych. Należy tu wymienić zwłaszcza Ricka Santoruma, który głosił, że partyjni rywale nie dostrzegają upadku moralnego Ameryki ${ }^{33}$. Jego skrajne wypowiedzi sprawiały jednak, że zdaniem analityków, choć mógł zyskać poparcie wyborców Partii Republikańskiej, to w rywalizacji z Obamą nie miałby większych szans. Trudno bowiem oczekiwać, by niezdecydowani wyborcy amerykańscy, z natury dość liberalni, poparli tak konserwatywnego polityka ${ }^{34}$. Jego poglądy w niektórych kwestiach były zbyt radykalne nawet dla wielu wyborców republikańskich. Tylko $36 \%$ kobiet i $22 \%$ mężczyzn głosujących na tę partię zgadzało się z nim, na przykład że aborcja powinna być zakazana bez względu na okoliczności ${ }^{35}$. Warto jednak zauważyć, że był on w swych postulatach wiarygodny. Republikańscy kan-

\footnotetext{
28 A. Kolar Prevost, J.A. Thurber, A perfect campaign, [w:] The 2008 presidential elections..., s. 112.

29 W. Modzelewski, USA w sondażach, Warszawa 2012, s. 21-22.

30 N.W. Polsby et al., op. cit., s. 27.

31 T. Płudowski, Dlaczego Amerykanie nie głosują?, [w:] Amerykańska demokracja w XXI wieku, red.
} A. Mania, P. Laidler, Kraków 2006, s. 229.

32 Diabet liberalizmu. Wywiad Oriane Raffin i Annelot Huijgen z Noamem Chomsky'm, „Wprost”, 14.12.2008, s. 93.

33 T. Zalewski, Kto głosuje na Myszkę Miki?, „Polityka”, 23.05.2012, s. 40.

34 P. Harris, Moherowy Rick, „Forum”, 5.03.2012, s. 10-13.

35 D.P. Kuhn, Is Santorum too socially conservative to defeat Obama?, www.realclearpolitics.com/articles/2012/02/19 (dostęp: 26.09.2015). 
dydaci uwidaczniali bowiem wtedy prawicowość swoich poglądów, by skontrastować je z polityką prezydenta Obamy. Dla Santoruma natomiast były one całkowicie naturalne $e^{36}$.

Problemem Mitta Romneya był z kolei brak poparcia ze strony Tea Party, gdyż zdaniem wielu jej przedstawicieli, zbyt łatwo zmieniał on poglądy w zależności od aktualnej potrzeby ${ }^{37}$. Są oni znani z silnego konserwatyzmu w kwestiach obyczajowych i sprzeciwu wobec socjalnej polityki państwa, a także zwiększania wydatków publicznych. Dziwić może fakt, że część przedstawicieli tego ruchu popierała byłego przewodniczącego Izby Reprezentantów - Newta Gingricha ${ }^{38}$. Niejednokrotnie bowiem popierał on inicjatywy sprzeczne z poglądami tej formacji. Był także po dwóch rozwodach, co jest dalekie od wartości wyznawanych przez konserwatywne kręgi republikańskie ${ }^{39}$. Wpisywał się natomiast w oczekiwania tradycyjnego elektoratu Republikanów, między innymi postulując otwarte prawo do posiadania broni ${ }^{40}$.

Partyjny establishment popierał jednak Mitta Romneya, starając się nie dopuścić do wzrostu popularności Gingricha. Republikanom trudno było znaleźć innego kandydata. Kongresmenka Michele Bachmann powtarzała, że chce być amerykańską żelazną damą i nawiązać swoją polityką do działań Ronalda Reagana i Margaret Thatcher, co miało wyciągnąć amerykańską gospodarkę z zapaści. Prezentowała poglądy konserwatywne, między innymi w kwestii małżeństw homoseksualnych ${ }^{41}$. W trakcie wypowiedzi publicznych często myliła jednak niektóre fakty, co powodowało, że jej popularność malała ${ }^{42}$. Wewnątrzpartyjna rywalizacja mogła w efekcie osłabiać pozycje kandydatów, podobnie jak miało to miejsce cztery lata wcześniej w Partii Demokratycznej podczas zmagań Baracka Obamy i Hillary Clinton.

Ostatecznie Romney bez większych trudności zapewnił sobie republikańską nominację. W przeszłości był on jednym z pierwszych przedstawicieli drapieżnego modelu kapitalizmu z lat 80 . XX wieku ${ }^{43}$. Wykupywał zadłużone przedsiębiorstwa, restrukturyzował je i sprzedawał z zyskiem, pozostawiając przy tym bez pracy wiele osób ${ }^{44}$. Inne jego działania także stawały się źródłem kontrowersji. W wyborach na gubernatora stanu Massachusetts odniósł zwycięstwo dzięki podporządkowaniu się liberalno-lewicowym preferencjom tamtejszych wyborców. Podczas urzędowania opowiadał się za prawem do aborcji, równouprawnieniem homoseksualistów oraz podniesieniem podatków. Kiedy w 2008 roku po raz pierwszy starał się zdobyć partyjną nominację, zdecydowanie zmienił swoje nastawienie na bardziej konserwatywne. Brak stałości poglądów mógł zatem stanowić jego słabość w oczach wyborców ${ }^{45}$.

\footnotetext{
36 P. Harris, op. cit., s. 10-13.

37 T. Deptuła, Polityczny android, „Newsweek”, 13.02.2012, s. 58-59.

38 T. Zalewski, Kto głosuje..., s. 39.

39 Idem, Gładki Mitt, szorstki Newt, „Polityka”, 3.01.2012, s. 47.

40 E. Schultheis, Newt: guns for all mankind, www.politico.com/blogs/burns-haberman/2012/04/ (dostęp: 28.09.2015).

41 I intend to be America's Iron Lady, www.realclearpolitics.com/video/2011 (dostęp: 29.09.2015).

42 M. Zawadzki, Republikanie mają dość, „Gazeta Wyborcza”, 24.02.2012, s. 14.

43 [b. a.] Romney czy Obama, co ich różni, który dla nas lepszy?, „Forum”, 22.10. 2012, s. 7.

44 P. Milewski, Chce być jak Obama, „Newsweek Polska”, 30.07.2012, s. 48.

45 T. Zalewski, Gładki Mitt..., s. 48.
} 
W kampanii prezydenckiej 2012 roku jego deklaracje programowe były natomiast zdecydowanie prawicowe. Romney i Obama przedstawiali zupełnie odmienne zapatrywania dotyczące zarówno kwestii społecznych, jak i gospodarczych. Uważano, że skala różnic pomiędzy ich poglądami jest największa od czasów rywalizacji Barry’ego Goldwatera $\mathrm{z}$ Lyndonem B. Johnsonem w 1964 roku ${ }^{46}$. Romney obiecywał obniżać wydatki federalne o 500 mld USD rocznie, dzięki czemu budżet miał zostać zbilansowany w ciągu ośmiu lat ${ }^{47}$. Postulował również zmniejszenie podatków dochodowych od osób fizycznych, zlikwidowanie podatków od dochodów z inwestycji, a także utworzenie w ciągu pierwszej kadencji $10 \mathrm{mln}$ nowych miejsc pracy. Jednocześnie chciał jednak zniesienia większości ulg o charakterze socjalnym ${ }^{48}$. Spory wpływ na postrzeganie Romneya miał także republikański kandydat na wiceprezydenta, Paul Ryan. Mówiło się, że jest on politycznym przeciwieństwem Obamy. Projekt budżetu, który w tym czasie przedstawił, stał się jednak przedmiotem ostrej krytyki. Zgodnie z jego założeniami, $62 \%$ oszczędności pochodziłoby z redukcji programów socjalnych ${ }^{49}$. Drastyczny program gospodarczy Ryana zakładał także likwidację w ciągu 10 lat systemu darmowej opieki medycznej dla emerytów oraz najbiedniejszych. Zmniejszone miały zostać także nakłady na system emerytalny, gdyż - zdaniem Ryana - te trzy programy pochłaniały $40 \%$ budżetu ${ }^{50}$. Postulował on również redukcję nakładów na edukację, ochronę środowiska i kulturę. Jego plan został negatywnie oceniony przez 58\% społeczeństwa. Oznaczało to, że postulaty takie odrzucali nie tylko zwolennicy Partii Demokratycznej, ale też kluczowi dla wyników głosowania, wyborcy niezależni ${ }^{51}$. Pogłębił się wobec tego negatywny stereotyp Romneya jako rzecznika interesów najbogatszych grup społecznych. Atakował on prezydenta, zarzucając mu, że swoimi wypowiedziami potęguje walkę klas i dzieli Amerykanów ${ }^{52}$.

Z kolei program Partii Demokratycznej, przyjęty przed wyborami w 2012 roku, stanowił kontynuację socjalnej polityki państwa. W kwestii zniwelowania długu publicznego, prezydent zapowiadał podniesienie podatku od zysków kapitałowych. Ponownie postulował także zwiększenie podatków od gospodarstw domowych, których dochody przekraczały 250 tys. USD rocznie oraz nałożenie minimum 30\% podatku od dochodów powyżej $1 \mathrm{mln}$ USD. Obama mówił także o konieczności zahamowania wzrostu opłat za studia i zapowiadał stworzenie miliona nowych miejsc pracy w przemyśle. Demokraci sprzeciwiali się także prywatyzacji w systemie opieki zdrowotnej ${ }^{53}$. Wyraźnie widoczna była chęć nakładania większych obciążeń na te grupy społeczeństwa, które znajdują się w korzystniejszej sytuacji ekonomicznej. Rywalizacja przybrała więc wymiar konfliktu

46 T. Paszewski, Wyzwania w cieniu kampanii prezydenckiej w Stanach Zjednoczonych, „Sprawy Międzynarodowe", red. H. Szlajfer, Warszawa LVX, 2012, nr 3, s. 39.

47 Obama and Romney on the issues, www.online.wsj.com/news/articles/SB10000872396390444464304 577537342693367910 (dostęp: 13.01.2015).

48 [b. a.] Romney czy Obama, Co ich różni?..., s. 8-9.

49 Z zacięciem do cięcia, „Forum”, 20.08.2012, s. 6.

50 M. Zawadzki, Kandydat Ryan, „Gazeta Wyborcza”, 13.08.2012, s. 8.

51 P. Milewski, Nowy pistolet republikanów, „Newsweek Polska”, 20.08.2012, s. 57-58.

52 T. Zalewski, Pijawka i arogant, „Polityka”, 23.05.2012, s. 65.

53 M. Zawadzki, Kto wyciagnie ludzi z domów, „Gazeta Wyborcza”, 6.11.2012, s. 10. 
ideologicznego, w którym Obama pełnił rolę orędownika większego wpływu państwa na gospodarkę, natomiast Romney jawił się jako zwolennik myśli libertariańskiej ${ }^{54}$.

Chcąc utrzymać poparcie mniejszości narodowych, Demokraci opowiadali się za gruntowną reformą systemu imigracyjnego, która miała polegać na uproszczeniu procedury przyznawania obywatelstwa dla osób przebywających w USA nielegalnie ${ }^{55}$. Romney prezentował $\mathrm{w}$ tej kwestii zupełnie odmienne stanowisko. Opowiadał się za zachęcaniem tej ludności do „samodeportacji” poprzez utrudnianie im pobytu na terenie USA. Postulował także budowę muru na granicy z Meksykiem. Stanowisko tak mało przychylne wobec imigrantów mogło się jednak wydawać ryzykowne w sytuacji ciągłego zwiększania się wpływu mniejszości narodowych na wynik wyborów ${ }^{56}$.

Znaczące różnice prezentowano $\mathrm{w}$ odniesieniu do spraw obyczajowych. Romney zdecydowanie przeciwstawiał się aborcji, chociaż jeszcze w 2002 roku był zwolennikiem prawa do przerywania ciąży ${ }^{57}$. Kandydat Republikanów sprzeciwiał się także prawnemu uznaniu małżeństw tej samej płci, uważając, że taka możliwość powinna zostać zabroniona poprzez wprowadzenie odpowiedniej poprawki do konstytucji ${ }^{58}$. Obama natomiast oświadczył, że jest zwolennikiem małżeństw jednopłciowych. Jego poglądy w tej kwestii ewoluowały zatem w porównaniu z wypowiedziami z 2008 roku. Był to krok mający zapewnić mu umocnienie poparcia w tej grupie elektoratu. Podobnymi deklaracjami Obama postawił się jednak w opozycji do około połowy społeczeństwa, która przeciwstawiała się takim małżeństwom. Prezydent mógł również stracić głosy bardzo ważnych dla niego Latynosów, a także Afroamerykanów, gdyż te grupy elektoratu prezentują poglądy mniej liberalne niż większość obywateli USA ${ }^{59}$.

Romney, dzięki silnie prawicowym poglądom Ryana, zyskał natomiast poparcie przedstawicieli Tea Party. Krytykowano go jednak za brak próby uzmysłowienia Amerykanom, że polityka socjalna obecnego prezydenta nie współgra z wolnorynkową ideologią, która przez 30 lat tworzyła amerykański dobrobyt. Laureat Nagrody Pulitzera, Charles Krauthammer pisał, że Amerykanie wiedzą, że dawny sukces nie został zbudowany na idei równych szans, a polegał na nagradzaniu ciężkiej pracy ${ }^{60}$.

W trakcie kampanii, Romney miał kilka niefortunnych wypowiedzi, które świadczyły o jego oderwaniu od standardów życia przeciętnych Amerykanów. We wrześniu 2012 roku ujawniono nagranie, które mogło zadecydować o wyniku wyborów. Romney powiedział wtedy: „Jest 47\% ludzi, którzy na mnie nie zagłosują, choćby nie wiem co. Oni są z Obamą. To ludzie zależni od państwa, którzy mają mentalność ofiar i wierzą, że rząd ma się nimi opiekować. Wierzą, że mają prawo do opieki zdrowotnej, do jedzenia, do dachu nad głową i do wszystkiego, co tylko można sobie wymyślić. Nie jest moją robotą troszczyć się o tych ludzi” ${ }^{\prime \prime}$. W mediach natychmiast zaczęły pojawiać się komentarze

\footnotetext{
54 T. Zalewski, Pijawka i..., s. 65.

55 G. Younge, Chicago: matecznik Baracka, „Forum”, 10.09.2012, s. 13.

56 [b. a.] Romney czy Obama, Co ich różni?..., s. 8-9.

57 M. Zawadzki, Wyborczy gwalt w USA, „Gazeta Wyborcza”, 22.08.2012, s. 10.

58 [b. a.] Romney czy Obama, Co ich różni?..., s. 8-9.

59 T. Zalewski, Od Milka do Obamy, „Polityka”, 16.05.2012, s. 52.

60 P. Foster, Mitt się rozwiat, „Forum”, 30.07.2012, s. 8-11

${ }^{61}$ M. Zawadzki, Mitt katastrofa Romney, „Gazeta Wyborcza”, 20.09.2012, s. 13.
} 
mówiące, że Romney przegrał tą wypowiedzią wybory. Szczególnie umocnił w postanowieniu oddania głosu na Obamę osoby z najmniej zamożnych kręgów społeczeństwa. Zbigniew Brzeziński stwierdził, że kampania z 2012 roku była najgorszą ze wszystkich, których był świadkiem. Jego zdaniem, zwłaszcza Romney nie stworzył wyraźnego profilu politycznego, a większość Amerykanów widziała w nim jedynie zaradnego przedsiębiorcę, co nie jest jednak wystarczające, by objąć urząd prezydenta ${ }^{62}$.

Wymienione czynniki spowodowały drugą z rzędu przegraną republikańskiego kandydata w wyborach prezydenckich. O wygranej Obamy w sporej mierze zadecydowało poparcie imigrantów. Urzędujący prezydent zdobył w tej grupie wyborców ponad 75\% głosów. Dla Partii Republikańskiej był to wyraźny znak, że oddalają się od ich preferencji oraz że nasilenie tego zjawiska również w przyszłości może pozbawić ich możliwości rządzenia krajem ${ }^{63}$.

Na podstawie badań instytutu Pew Research Center można przeanalizować dane dotyczące rozkładu poparcia wśród wyznawców poszczególnych religii. Czynnik ten ma w odniesieniu do społeczeństwa amerykańskiego spore znaczenie, gdyż w sondażach jedynie około $5 \%$ obywateli deklaruje się jako niewierzący w Boga ${ }^{64}$. W trakcie kampanii kandydaci prezentowali wiele wypowiedzi odnoszących się do sfery obyczajowej, co mogło mieć znaczący wpływ na preferencje osób zaangażowanych religijnie (tab. 2).

Tabela 2. Rozkład poparcia dla kandydatów w zależności od wyznania wyborców

\begin{tabular}{l|c|c|c}
\hline \multicolumn{1}{c|}{ Wyznanie } & $\begin{array}{c}\text { Poparcie dla } \\
\text { Baracka Obamy (\%) }\end{array}$ & $\begin{array}{c}\text { Poparcie dla } \\
\text { Mitta Romneya (\%) }\end{array}$ & $\begin{array}{c}\text { Zmiany poparcia dla } \\
\text { Baracka Obamy } \\
\text { w porównaniu } \\
\text { z 2008 rokiem (\%) }\end{array}$ \\
\hline Protestanci & 42 & 57 & -3 \\
\hline Protestanci rasy białej & 30 & 69 & -4 \\
\hline Protestanci rasy czarnej & 95 & 5 & +1 \\
\hline Katolicy & 50 & 48 & -4 \\
\hline Katolicy rasy białej & 40 & 59 & +7 \\
\hline Latynosi & 75 & 30 & -9 \\
\hline Żydzi & 69 & 78 & Brak danych \\
\hline Mormoni & 21 & 23 & +1 \\
\hline Wyznawcy innych religii & 74 & 26 & -5 \\
\hline Niezaangażowani & 70 & 41 & +3 \\
\hline
\end{tabular}

Źródło: J. Bickel/Corbis, How the faithful voted 2012: preliminary analysis, www.pewforum.org/2012/11/07/how-thefaithful-voted-2012-preliminary-exit-poll-analysis/ (dostęp: 14.01.2015).

${ }^{62}$ Kampanię obserwuje z konsternacja. Wywiad Macieja Nowickiego ze Zbigniewem Brzezińskim, „Newsweek”, 3.09.2012, s. 64.

63 T. Zalewski, Ciężkie życie zwycięzcy, „Polityka”, 14.11.2012, s. 50.

64 S. Huntington, Kim jesteśmy? Wyzwania dla amerykańskiej tożsamości narodowej, Kraków 2007, s. 85. 
Zgodnie z przewidywaniami, Romney — postrzegany jako kandydat o bardziej konserwatywnych poglądach - zdecydowanie zwyciężył wśród protestantów. W gronie białych przedstawicieli tej grupy religijnej jego poparcie było szczególnie wysokie i wyniosło niemal 70\%. Warto jednak zwrócić uwagę, że od 2008 roku ta grupa elektoratu zmniejszyła się o $3 \%{ }^{65}$. W przypadku protestanckich Afroamerykanów czynnik rasowy miał determinujące znaczenie i pomimo liberalnych poglądów Obamy nie przeszkodziło mu to w zdobyciu 95-procentowego poparcia tej części elektoratu. Kandydat Demokratów zdobył również więcej głosów wśród katolików. Decydujący wpływ miała na to zdecydowana przewaga głosów uzyskanych od Latynosów. Romney zdecydowanie zwyciężył w głosowaniu mormońskich współwyznawców, liberalne poglądy zapewniły jednak Obamie aż 70\% poparcia wśród wyborców niezaangażowanych religijnie.

Zaskoczeniem nie był także rozkład poparcia w zależności od pochodzenia etnicznego wyborców (tab. 3). Jedyną grupą, w której przewagę uzyskał Romney, była ludność rasy białej. Jej przedstawiciele stanowili jednak aż 72\% wyborców. Jeszcze dwie dekady wcześniej uzyskanie w gronie białych wyborców aż o $20 \%$ więcej głosów zapewniłoby zdecydowaną wygraną ${ }^{66}$.

Tabela 3. Rozkład poparcia dla kandydatów wśród poszczególnych grup etnicznych

\begin{tabular}{l|c|c|c}
\hline \multicolumn{1}{c|}{ Grupa etniczna } & $\begin{array}{c}\text { Odsetek w skali } \\
\text { społeczeństwa }\end{array}$ & $\begin{array}{c}\text { Poparcie dla } \\
\text { Baracka Obamy (\%) }\end{array}$ & $\begin{array}{c}\text { Poparcie dla } \\
\text { Mitta Romneya (\%) }\end{array}$ \\
\hline Biali & 72 & 39 & 59 \\
\hline Afroamerykanie & 13 & 93 & 6 \\
\hline Latynosi & 10 & 71 & 27 \\
\hline Azjaci & 3 & 73 & 38 \\
\hline Inni & 2 & 58 & 26 \\
\hline
\end{tabular}

Źródło: Exit polls 2012: How the vote has shifted, www.washingtonpost.com/wp-srv/special/politics/2012-exit-polls/ table.html (dostęp: 14.01.2015).

Podobną do 2008 roku tendencję można było zauważyć, analizując rozkład głosów w zależności od wielkości dochodów. Im mniej zamożna była dana grupa wyborców, tym Obama zyskiwał większe poparcie. Jednocześnie grupa najmniej zarabiających była najliczniejsza i stanowi $41 \%$ głosujących ${ }^{67}$. Podtrzymanie socjalnej linii programowej okazało się wobec tego trafne i zapewniło poparcie milionów wyborców obawiających się wolnorynkowych zapatrywań Romneya.

Jonathan Franzen, amerykański powieściopisarz, twierdził, że Partia Republikańska nie zauważa zmian zachodzących w amerykańskim społeczeństwie. Coraz bardziej oddalają się przez to na przykład od preferencji kobiet z klasy średniej. Tracą również

65 J. Bickel/Corbis, How the faithful voted 2012: preliminary analysis, www.pewforum.org/2012/11/07/ how-the-faithful-voted-2012-preliminary-exit-poll-analysis/ (dostęp: 14.01.2015).

66 M. Zawadzki, Znów Obama, czyli nowa Ameryka, „Gazeta Wyborcza”, 8.11.2012, s. 1.

67 Exit polls 2012: How the vote has shifted, www.washingtonpost.com/wp-srv/special/politics/2012-exit-polls/table.html (dostęp: 15.01.2015). 
głosy Latynosów, prawie wszystkich Afroamerykanów oraz Azjatów. Podstawową grupą popierającą ich pozostają biali mężczyźni, ale znaczenie tej grupy wyborców z biegiem lat maleje. Wśród tych środowisk panuje niechęć do Obamy, który jest symbolem nastających zmian ${ }^{68}$.

Udana kampania wyborcza, kontynuacja polityki pomocy ze strony państwa, ale też dokonania w okresie sprawowania urzędu po raz kolejny zapewniły Obamie poparcie Afroamerykanów i Latynosów. Liberalne poglądy umożliwiły natomiast podtrzymanie popularności wśród większości młodzieży, kobiet i mieszkańców wielkich miast. Dla wielu wyborców kandydatura Obamy jawiła się jako bezpieczniejszy wybór. Romneya natomiast, ceniono jako sprawnego biznesmena, ale nie był on gwarantem pewnej przyszłości dla wielu obywateli. Obama, zwłaszcza przy uwzględnieniu zmian społecznych zachodzących w amerykańskim społeczeństwie, prezentował program lepiej dostosowany do oczekiwań większości wyborców, co było jednym z kluczowych czynników, które zapewniły mu reelekcję.

\section{Problemy prawicy}

Analizując wybory prezydenckie w USA w latach 2008 i 2012, można dostrzec pewne nasilające się tendencje. Partia Republikańska ma wyraźny problem z wyłonieniem polityka niewzbudzającego większych kontrowersji, który mógłby zdobyć poparcie wielu grup wyborców. W ostatnich latach w przypadku Republikanów można dostrzec też wewnątrzpartyjne konflikty i powstające tam frakcje. Wiąże się to z radykalizowaniem się poglądów niektórych polityków tego ugrupowania, czego wyrazem jest wzrost znaczenia Tea Party. Wynika to z protestów niektórych środowisk republikańskich wobec zbyt socjalnej - ich zdaniem - polityki władz. Konserwatywne kręgi Partii Republikańskiej coraz silniej występują też w obronie tradycyjnych wartości, które w ich opinii są zagrożone ze względu na postępującą liberalizację społeczeństwa. Konflikty w łonie amerykańskiej prawicy wpływają jednak negatywnie na szanse ich kandydatów w wyborach prezydenckich. Ani McCain, ani Romney nie mieli pełnego poparcia swojej partii.

Niezmiennie kandydatom prawicy trudno zdobyć poparcie imigrantów i Afroamerykanów. Jeb Bush - brat George’a W. Busha, stwierdził, że Partia Republikańska musi zmienić swoją politykę, w 2012 roku Latynosi stanowili już bowiem kilkanaście procent społeczeństwa, a w 2050 roku - według prognoz - mają oni stanowić około 1/3 obywateli. Bez ich głosów, zdaniem Busha, nie będzie można wygrać żadnych wyborów ${ }^{69}$. Republikańscy kandydaci nadal wygrywają jednak w stanach południowych oraz położonych w centrum kraju, gdzie przeważają wyborcy konserwatywni. Elektorat Partii Republikańskiej na przestrzeni czterech lat również uległ pewnym przeobrażeniom. Zgodnie z badaniami „New York Times”, w stosunku do wyborów z 2008 roku, wśród

68 Strach i euforia. Wywiad Maciej Nowickiego z Jonathanem Franzenem, „Newsweek Polska”, 12.11.2012, s. 80 .

69 M. Zawadzki, Kto na Florydzie przerwie wyborczy klincz?, „Gazeta Wyborcza”, 31.01.2012, s. 9. 
zwolenników tej partii więcej było osób ulegających populizmowi, słabiej wykształconych oraz zwiększył się w tej grupie odsetek białej społeczności. Spowodowało to rozłam kulturowy pomiędzy establishmentem a szeregowymi członkami, przekładający się na opcję laicką i religijną ${ }^{70}$. Należy jednak zaobserwować, że poparcie dla Republikanów rośnie głównie w tych grupach elektoratu, które z biegiem lat stanowią coraz mniejszy odsetek amerykańskiego społeczeństwa. Próby dotarcia jedynie do tradycyjnych kręgów wyborców okazywały się jednak niewystarczające.

Sporo podobieństw można zauważyć, porównując wyniki głosowania z lat 2008 i 2012. Obama dwukrotnie zwyciężył wśród ludzi młodych, kobiet, mniejszości etnicznych i seksualnych oraz osób mniej zamożnych. W analizie przestrzennego rozkładu głosów widać, że zarówno w 2008, jak i 2012 roku w stanach leżących na obu wybrzeżach — gdzie znajdują się duże aglomeracje miejskie - w zdecydowanej większości triumfował kandydat Partii Demokratycznej. W stosunku do poprzednich wyborów, w 2012 roku zwiększyła się solidarność zwolenników Partii Demokratycznej i Republikańskiej wobec kandydatów ich ugrupowań. W 2008 roku McCain zdołał przejąć głosy 10\% wyborów demokratycznych, natomiast Obama uzyskał 9\% głosów Republikanów. Cztery lata później Obama przejął już tylko 6\% głosów wyborców republikańskich, a Romney uzyskał 7\% wśród zwolenników Demokratów. Widoczne jest w tym kontekście nasilanie podziałów pomiędzy elektoratami tych partii.

\section{Podsumowanie}

Republikanie napotkali problem związany z tym, czy pozostać wiernym swej tradycyjnej linii poglądowej, czy też zmieniać swój program wyborczy, by dostosować go do oczekiwań społecznych. Partia Republikańska, chcąc zwiększyć swoje szanse w 2016 roku, musiałaby zatem zmienić swoje nastawienie w kwestiach ekonomicznych, godząc się na rozwiązania o charakterze bardziej socjalnym oraz łagodząc swoje stanowisko wobec imigrantów. Pozwoli to na zdobycie większego poparcia ze strony Latynosów. Grupa ta - coraz ważniejsza dla wyników wyborów - wykazuje spore zaangażowanie religijne, co zbliża ich do republikańskich konserwatywnych zapatrywań. W 2016 roku Demokraci nie nominują już czarnoskórego Obamy, z którym identyfikowała się i którego popierała, ogromna większość Afroamerykanów. Może to ułatwić Republikanom pozyskanie nowych kręgów wyborców. Wzrost znaczenia skrajnie prawicowej Tea Party w ramach Partii Republikańskiej może jednak utrudniać zmiany postulatów programowych przez jej kierownictwo. Wtedy reprezentant Demokratów może rządzić w Białym Domu przez kolejną, trzecią kadencję.

70 P. Harris, Moherowy..., s. 13. 


\section{Bibliografia}

Co się stało w Ameryce? Wywiad Jacka Żakowskiego z Radosławem Markowskim, „Polityka”, 8.11.2008.

Deptuła T., Polityczny android, „Newsweek”, 13.02.2012.

Diabet liberalizmu. Wywiad Oriane Raffin i Annelot Huijgen $z$ Noamem Chomsky'm, „Wprost”, 14.12.2008.

Duggin S.H., Collins M.B., The American Presidency, the 2008 election, and the U.S. constitutions natural born citizens proviso, [w:] Wybory w USA - z zagadnień teorii i praktyki, „Krakowskie Studia Międzynarodowe", red. B. Bednarczyk, Kraków V, 2008, nr 3.

Dziemidziok-Olszewska B., System polityczny Stanów Zjednoczonych, [w:] Współczesne systemy polityczne, red. M. Żmigrodzki, B. Dziemidziok-Olszewska,Wydawnictwo Naukowe PWN, Warszawa 2007.

Foster P., Mitt się rozwiat, „Forum”, 30.07.2012.

Gans Jr. J.A., The democratic primaries, [w:] The 2008 presidential elections. A story in four acts, red. E. Jones, S. Vassallo, Palgrave Macmillan, New York 2009.

Harris P., Moherowy Rick, „Forum”, 5.03.2012.

Heilemann J., Halperin M., Game change, Obama and the Clintons, McCain and Palin, and the race of a lifetime, Harper Perennial, New York 2010.

Huntington S., Kim jesteśmy? Wyzwania dla amerykańskiej tożsamości narodowej, Znak, Kraków 2007.

Kampanię obserwuję z konsternacją. Wywiad Macieja Nowickiego ze Zbigniewem Brzezińskim, „Newsweek”, 3.09.2012.

Kolar Prevost A., Thurber J.A., A perfect campaign, [w:] The 2008 presidential elections. A story in four acts, red. J. Eric, S. Vassallo, ABC-CLIO, New York 2009.

Kozłowski S.G., Bieda po amerykańsku, „Le Monde Diplomatique” V, 2008, nr 5.

Laidler P., Na czym polega fenomen Baracka Obamy?, [w:] Wybory w USA - z zagadnień teorii i praktyki, „Krakowskie Studia Międzynarodowe”, red. B. Bednarczyk, Kraków V, 2008, nr 3.

Milewski P., Chce być jak Obama, „Newsweek Polska”, 30.07.2012.

Milewski P., Nowy pistolet republikanów, „Newsweek Polska”, 20.08.2012.

Modzelewski W., USA w sondażach, Difin, Warszawa 2012.

Norrander B., Democratic marathon, republican sprint. The 2008 presidential nominations, [w:] The American elections of 2008, red. J.M. Box-Steffensmeier, S.E. Schier, Rowman \& Littlefield Publishers, Maryland 2009.

Obamiacy, hillaryści, makkejnowcy. Wywiad Jarosława Makowskiego z Profesorem Tomaszem Tabako, „Polityka”, 21.06.2008.

Ostrowski M., Do kogo zadzwoni Ameryka?, „Polityka”, 5.04.2008.

Paszewski T., Wyzwania w cieniu kampanii prezydenckiej w Stanach Zjednoczonych, [w:] „Sprawy Międzynarodowe", red. H. Szlajfer, Warszawa LVX, 2012, nr 3.

Płudowski T., Dlaczego Amerykanie nie głosują?, [w:] Amerykańska demokracja w XXI wieku, red. A. Mania, P. Laidler, Wydawnictwo Uniwersytetu Jagiellońskiego, Kraków 2006.

Polsby W.N. et al., Presidential elections. Strategies and structures of American politics, Rowman \& Littlefield, Maryland 2012.

Pułło A., Wstęp, [w:] Konstytucja Stanów Zjednoczonych Ameryki, red. L. Garlicki, Wydawnictwo Sejmowe, Warszawa 2002.

Punkty za pochodzenie. Wywiad Marka Ostrowskiego z Christophem von Marschallem, „Polityka”, 20.09.2008.

[b. a.] Romney czy Obama, co ich różni, który dla nas lepszy?, „Forum”, 22.10.2012.

Sarnecka-Mahoney E., Odziedziczona rewolucja. Dlaczego Obama, dlaczego teraz, co dalej z ta Ameryka, Prószyński Media, Warszawa 2009.

Strach i euforia. Wywiad Maciej Nowickiego z Jonathanem Franzenem, „Newsweek Polska”, 12.11.2012.

Smidt C.E. et al., The Disappearing God gap? Religion in the 2008 presidential election, Oxford University Press, New York 2010.

Young G., Chicago: matecznik Baracka, „Forum”, 10.09.2012. 
Zalewski T., Ciężkie życie zwycięzcy, „Polityka”, 14.11.2012.

Zalewski T., Czy w Denver poleje się krew?, „Polityka”, 3.05.2008.

Zalewski T., Gładki Mitt, szorstki Newt, „Polityka”, 3.01.2012.

Zalewski T., Kościoły czarne i białe, „Polityka”, 31.03.2008.

Zalewski T., Kto głosuje ma Myszkę Miki?, „Polityka”, 23.05.2012.

Zalewski T., Od Milka do Obamy, „Polityka”, 16.05.2012.

Zalewski T., Pijawka i arogant, „Polityka”, 23.05.2012.

Zakaria F., Koniec hegemonii Ameryki, Nadir, Warszawa 2009.

Zawadzki M., Kandydat Ryan, „Gazeta Wyborcza”, 13.08.2012.

Zawadzki M., Kto na Florydzie przerwie wyborczy klincz?, „Gazeta Wyborcza”, 31.01.2012.

Zawadzki M., Kto wyciagnie ludzi z domów, „Gazeta Wyborcza”, 6.11.2012.

Zawadzki M., Mitt katastrofa Romney, „Gazeta Wyborcza”, 20.09.2012.

Zawadzki M., Obama odrodzony, „Gazeta Wyborcza”, 8.11.2012.

Zawadzki M., Republikanie mają dość, „Gazeta Wyborcza”, 24.02.2012.

Zawadzki M., Wyborczy gwalt w USA, „Gazeta Wyborcza”, 22.08.2012.

Zawadzki M., Znów Obama, czyli nowa Ameryka, „Gazeta Wyborcza”, 8.11.2012.

Z zacięciem do cięcia, „Forum”, 20.08.2012.

Żebrowski W., Teoria współczesnych systemów politycznych, Wydawnictwo Uniwersytetu Warmińsko-Mazurskiego, Olsztyn 2009.

\section{Źródła internetowe}

Barr A., 2008 turnout shatters all records, www.politico.com/news/stories/1108/15306.html

Bickel/Corbis J., How the faithful voted 2012: preliminary analysis, www.pewforum.org/2012/11/07/howthe-faithful-voted-2012-preliminary-exit-poll-analysis/

Blueprint for change, Obama and Biden's Plan for America, www.slideshare.net/arepb/blueprint-for-changeobamas-plan-for-america-presentation

Exit polls 2012: How the vote has shifted, www.washingtonpost.com/wp-srv/special/politics/2012-exit-polls/ table.html

Gibson J, A brieflook at candidate Obama's 2008 campaign promises, www.foxnews.com/politics/2011/04/05/ brief-look-at-candidate-obama-2008-campaign-promises

I intend to be America's Iron Lady, www.realclearpolitics.com/video/2011

Kuhn D.P., Is Santorum too socially conservative to defeat Obama?, www.realclearpolitics.com/articles/2012/02/19

Obama and Romney on the issues, www.online.wsj.com/news/articles/SB1000087239639044446430457753 734269336790

Rosenthal A., Now for a real underdog, Ron Paul, libertarian, for president, www.nytimes.com/1988/10/17/ us/now-for-a-real-underdog-ron-paul-libertarian-for-president.html

Schultheis E., Newt: guns for all mankind, www.politico.com/blogs/burns-haberman/2012/04/

Wrocławskie Studia Politologiczne 20, 2016

(C) for this edition by CNS 


\section{The candidates of the Democratic Party and the Republican Party in the face of the socio-economic changes. An analysis based on the example of presidential elections of 2008 and 2012}

Keywords: party, democratic, Republican, elections, changes

Summary

American society has been the subject of many changes in recent years. In this context, important was an increasing liberalization of communities of large cities. But also, as a response to this process, there could be seen a growing influence of the conservative Tea Party supporters. Changes in the national structure consisting of reducing the share of white community for African Americans and immigrants are also noticeable. Important implications also caused the recent economic crisis resulting in differentiation of the standard of living of different social groups. It is therefore interesting to analyze how two major American parties responded to these changes. The ground for such an analysis are especially presidential elections because of the importance that the head of state has in the policy of the United States. 